\title{
Growth dynamics of the Norway spruce and silver fir understory in continuous cover forestry
}

\author{
Jaroslav Vencurik ${ }^{(1)}$, \\ Stanislav Kucbel ${ }^{(1)}$, \\ Milan Saniga ${ }^{(1)}$, \\ Peter Jaloviar ${ }^{(1)}$, \\ Denisa Sedmáková ${ }^{(1)}$, \\ Ján Pittner ${ }^{(1)}$, \\ Zuzana Parobeková (1), \\ Michal Bosela ${ }^{(2)}$
}

\begin{abstract}
The conversion to uneven-aged, mixed-species stands represents one possible way to mitigate the consequences of disturbances in Norway spruce forests in Central Europe. A better understanding of the establishment and growth dynamics of the understory can contribute to a more effective conversion process. Here we investigate the structure of understory, light climate and growth of natural regeneration of Norway spruce and silver fir in two forest stands undergoing conversion to continuous cover forestry. Stand-wise forest inventory was conducted in 1993 and 2013. The natural regeneration was surveyed, and the light conditions and inter-tree competition were quantified in 51 sample plots established across the stands in 2013. Our results suggest that the diffuse radiation strongly affects the height growth of fir and spruce natural regeneration. We do not confirm the effect of local sapling density on the regeneration dynamics. The results further show that fir trees grow faster than spruce under less intensity of diffuse light. Most of the spruce and fir trees reached the upper limit of the lower overstory (DBH $12 \mathrm{~cm}$ ) at approximately 50 years of age. Thus, more substantial reductions in stand density can lead to a well-differentiated structure in less than five decades. To control the prospective representation of spruce and fir in mixed-species forests undergoing the conversion, managing of light conditions is crucial.
\end{abstract}

Keywords: Conversion to Selection Forest, Natural Regeneration, Height Growth, Diffuse Light

\section{Introduction}

Most of the stands dominated by Norway spruce (Picea abies [L.] Karst.) in Central Europe originated from traditional evenaged management. They are productive yet rather unstable forest ecosystems that are often threatened by windthrows, bark beetle outbreaks (Schütz et al. 2006, Mezei et al. 2014), nutrient leaching and accelerated soil acidification (Augusto et al. 2002) and recently also by climate change (Boden et al. 2014, Bošela et al. 2014, Seidl et al. 2017). The negative impact of these factors together with current trends emphasizing the advantages of incorporating close-to-nature principles into silvicultural management encourages the conversion of pure Norway spruce forests into uneven-aged, mixed-species stands (Gam-

borg \& Larsen 2003). It is assumed that structurally diverse and mixed-species forests have higher adaptation potential when exposed to unpredictable stress or disturbances (Brang et al. 2014). As a traditional multi-aged silvicultural system, single-tree selection (also known as Plenterwald) represents one of the appropriate alternatives for this transformation (Von Lüpke et al. 2004). Stand structures of this kind are considered stable and able to continuously produce high-quality timber. In comparison with even-aged plantations, intensively managed selection forests are usually formed by silver fir (Abies alba Mill.) with an admixture of Norway spruce and European beech (Fagus sylvatica L.) mixed at small spatial scales (Schütz 2001a). In conifer-dominated mixed stands, silver fir
(1) Department of Silviculture, Faculty of Forestry, Technical University in Zvolen, Masarykova 24, 96053 Zvolen (Slovak Republic); (2) Department of Forest Management and Geodesy, Faculty of Forestry, Technical University in Zvolen, Masarykova 24, 96053 Zvolen (Slovak Republic)

\section{@ Jaroslav Vencurik (vencurik@tuzvo.sk)}

Received: Jul 03, 2019 - Accepted: Nov 28, 2019

Citation: Vencurik J, Kucbel S, Saniga M, Jaloviar P, Sedmáková D, Pittner J, Parobeková Z, Bosela M (2020). Growth dynamics of the Norway spruce and silver fir understory in continuous cover forestry. iForest 13: 56-64. - doi: 10.3832/ifor3183-012 [online 2020-02-05]

Communicated by: Davide Ascoli is a species known to be more tolerant to higher temperatures and drought (Van Der Maaten-Theunissen et al. 2013, Vitali et al. 2018) and to have greater resistance to wind and insect damage than Norway spruce (Dengler 1980, Dvorak et al. 2001); thus, its increased proportion in converted stands can promote forest stability. However, the key assumption is the elimination of browsing by ungulates (Heuze et al. 2005).

The process of conversion from homogenous to multi-aged stand structures is a complicated and long-lasting task. Its realization depends on the initial condition of the respective forest stand and, according to Schütz (2001a), the conversion has to consider stand stability, the life expectancy of the canopy trees, structural diversification and the prospects for regeneration establishment. Natural regeneration plays a crucial role in the whole process and is the necessary precondition for forming the overstory. One of the main factors regulating the species composition, spatial distribution and development of natural regeneration is the light environment. Variability in the light microclimate in canopy gaps allows the establishment and growth of tree species with diverse ecological requirements (Filipiak et al. 2005, Szymura 2005, Stancioiu \& O'Hara 2006, Diaci \& Firm 2011). In stands undergoing conversion to singletree selection, low light intensity favours the natural regeneration of semi-shade- 
(Norway spruce) and shade-tolerant species (silver fir and European beech - Schütz $2001 \mathrm{~b})$. Seedlings and saplings of these tree species are able to survive and grow under low light intensities (Cescatti 1996, Diaci \& Firm 2011). In shaded conditions, silver fir has a competitive advantage because it is able to achieve a positive carbon balance at a lower radiation intensity than Norway spruce (Grassi \& Bagnaresi 2001, Prpić \& Seletković 2001). This advantage is attributed, in particular, to the superior morphological plasticity of fir saplings' crowns and to the more efficient photosynthetic capacity of fir needles growing under low light levels. Crown morphology therefore significantly influences the utilization of diffuse light, resulting in faster height growth and the differences in competitiveness of spruce and fir in the understory (Robakowski et al. 2004, Grassi \& Giannini 2005).

Unlike the regeneration cuts applied in even-aged stands (e.g., regular shelterwood cut), where the light conditions are much more homogenous and bound to certain stand area, the distribution of light in stands undergoing conversion to singletree selection is spatially diverse, dominated by small sunflecks of short duration that supply almost all light required for natural regeneration (Schütz 2001b). Heterogeneous vertical canopy structure and irregular distribution of natural regeneration cause high variability of light conditions and modify the strength of inter- and intraspecific competition within the cohorts of natural regeneration (Duchesneau et al. 2001, Grassi et al. 2004, Lin et al. 2012, Danescu et al. 2018). On the other hand, deliberate regulation of light and competition in understory has a significant impact on subsequent changes in stand structure and tree species composition (Danescu et al. 2018). Therefore, detailed insights into the growth processes of understory trees in the specific conditions of stands undergoing conversion may help to manage the process of conversion following principles of close-to-nature forest management more effectively. Under the ongoing climate change, maintaining the appropriate spruce-fir (beech) ratio in regeneration as well as in the mature stands represents the crucial task of the silvicultural treatments. Moreover, for the planning of conversions in vulnerable spruce stands it is important to quantify also the time-frames needed for the achievement of irregular structure (Von Lüpke et al. 2004).

The goal of the present study was to examine and better understand the differences between the growth dynamics of Norway spruce and silver fir in the understory of forest stands undergoing conversion to selection forests. The particular objectives of the study were to (i) assess the tree species composition of regeneration and analyse the sapling density in relation to light conditions; (ii) quantify the effect of site, light conditions and neighbourhood characteristics on height growth and selected morphological attributes of Norway spruce and silver fir saplings; and (iii) quantify the time needed for regeneration to grow into the overstory.

\section{Materials and methods}

\section{Study area}

The study was conducted in two conifer forest stands (D1A and D2C) in an advanced phase of conversion to selection forests, growing on different sites. The study area is situated in the southwestern part of the Nízke Tatry Mountains ( $48^{\circ} 52^{\prime} \mathrm{N}, 19^{\circ} 14^{\prime} \mathrm{E}$ ) in Central Slovakia. Since the 1980s, the stands have been part of the demonstration area Donovaly-Mistríky (50.3 ha), established by the Technical University in $\mathrm{Zv}$ olen, to follow the effects of silvicultural interventions on the structure and development of forest stands in various phases of conversion to selection forests (Saniga \& Vencurik 2007). The investigated stands, covering 3.58 ha (D1A) and 2.50 ha (D2C), are located at an altitude of $900-950 \mathrm{~m}$ a.s.l. on a NW slope. The parent material is represented by granite, and the dominant soil types are shallow, acidic, nutrient-poor umbric leptosols (Vencurik et al. 2016). The mean annual temperature reaches 4.2-4.5 ${ }^{\circ} \mathrm{C}$, and the mean annual precipitation is $1000-1100 \mathrm{~mm}$. The D1A and D2C differ in slope (25\% and $85 \%$, respectively) and soil skeleton content ( $30 \%$ and $65 \%$ on average, respectively), resulting in more severe growth conditions and lower productive potential in the D2C. The site index (defined as the height of dominant trees at the age of 100 years) reaches 28 for the spruce and 26 for the fir trees in the D1A, and 24 for the spruce and 20 for the fir trees in the $D_{2} C$. The ground vegetation is dominated by Vaccinium myrtillus L., with a cover of $36 \%$ in the $\mathrm{D}_{1} \mathrm{~A}$ and $48 \%$ in the $\mathrm{D}_{2} \mathrm{C}$ (Vencurik et al. 2016). In the whole area, the forests are classified as Piceion excelsae (Pawlowski et al. 1928). The dominant tree species in the investigated stands is Norway spruce. Before the start of the conversion process, the proportion of Norway spruce reached in the D1A $75 \%$ and in the D2C 99\% of the growing stock (data from the local Forest Management Plan from 1978). The rest of the growing stock was largely dominated by silver fir, with a minor proportion (1-3\%) of European larch (Larix decidua Mill.), Scots pine (Pinus sylvestris L.) and rowan (Sorbus aucuparia L.). European beech, once the natural admixture in fir-spruce forests, was eliminated from the stands due to charcoal production at the end of the $18^{\text {th }}$ century. Intending to restore its presence, small groups of beech were underplanted in the stands in 1981-85. The groups were located mostly within existing gaps, and 3-year-old seedlings were used for the underplanting. The number of underplanted beech seedlings was $350 \mathrm{ha}^{-1}$ in the D1A and 400 ha $^{-1}$ in the D2C (Saniga \& Vencurik 2007). The initial structure of the investigated stands before the start of the conversion process in the early 1980 s was already partly differentiated. At the beginning of the study in 1993, the stands were already in an advanced stage of conversion. The last deliberate silvicultural intervention was applied in 1995. The selection cutting with intensities of $78 \mathrm{~m}^{3} \mathrm{ha}^{-1}$ (D1A) and $32 \mathrm{~m}^{3} \mathrm{ha}^{-1}\left(\mathrm{D}_{2} \mathrm{C}\right)$ was mainly focused on the reduction of stems in the overstory. In the following period, the silvicultural interventions in both stands were limited to sanitation cuttings of windthrown Norway spruce, reaching an intensity of $53 \mathrm{~m}^{3} \mathrm{ha}^{-1}$ in the D1A and $4 \mathrm{~m}^{3} \mathrm{ha}^{-1}$ in the D2C (data according to local Reports on the Annual Harvest from 1993-2013). Regarding the damage by ungulates, the experimental setting was representative of standard forest management conditions with no special protection measures (e.g., fencing) and browsing controlled by hunting.

\section{Data collection}

The diameter distribution data (overstory trees with $\mathrm{DBH}>8 \mathrm{~cm}$ ) originated from full callipering conducted in the studied stands in 1993 and 2013. Regeneration (trees with $\mathrm{DBH} \leq 8 \mathrm{~cm}$ ) was surveyed in 31 (D1A) and 20 (D2C) sample plots established in a regular grid of $35 \times 35 \mathrm{~m}$ in 2013. Each sample plot consisted of two concentric circles $\left(250 \mathrm{~m}^{2}\right.$ and $\left.100 \mathrm{~m}^{2}\right)$ and a square $\left(25 \mathrm{~m}^{2}\right)$ located in the centre. In the central $5 \times 5 \mathrm{~m}$ square, for the trees in the "seedlings" (height $\leq 20 \mathrm{~cm}$, excluding one-year-old seedlings) and "younger saplings" (height 20-130 cm) categories, we recorded the tree species and height. In the circle of 100 $\mathrm{m}^{2}$, the trees classified as "older saplings" (height $>130 \mathrm{~cm}, \mathrm{DBH} \leq 4 \mathrm{~cm}$ ) were sampled, and we recorded the tree species, DBH and height. In the circle of $250 \mathrm{~m}^{2}$, the trees in the category "undergrowth" (DBH 4-8 $\mathrm{cm}$ ) were measured using the same parameters as those used for the older saplings. In all the regeneration categories, we also registered the presence of mechanical damage (broken terminal shoot) and damage by ungulates, i.e., browsing and bark stripping. For a detailed analysis of tree growth, we selected 65 Norway spruce and 65 silver fir trees from the older saplings category in each stand (260 trees in total). The saplings were chosen to cover the entire range of light and competition conditions and were randomly distributed throughout the investigated stands. Saplings with visible damage and located in the vicinity of recent cuttings were excluded from the analysis. If the saplings were growing in a cluster, we selected the highest tree. For this set of older saplings, we recorded the tree species, DBH, height, the length of the terminal and lateral shoots located on the upper three whorls and the length of the whole live crown from the top to the last live branch. The shoot lengths were measured using a telescopic measuring rod mEssfix- $\mathrm{S}^{\otimes}$ (Nedo, Dornstetten, Germany) with a range of 8 
$\mathrm{m}$. Subsequently, we calculated the following characteristics (sensu Szymura 2005): the mean annual height increment of the last 3 years, the apical dominance ratio (ratio between the lengths of the terminal and lateral shoot located on the third whorl), the relative growth ratio (mean annual height increment of the last 3 years/ tree height $\times 100$ ) and the relative crown length (length of live crown/tree height $x$ 100). Moreover, for each selected older sapling, the intensity of competition was quantified using a competition index (Duchesneau et al. 2001, Grassi \& Giannini 2005) that considered the competing trees inside a $4 \mathrm{~m}^{2}$ large circular area $(1.13 \mathrm{~m}$ radius) surrounding the sapling. The area was divided into four quadrants, and the competition index (I) was calculated according to the following formula (eqn. 1):

$$
I=\frac{1}{H_{O S}} \cdot \frac{1}{4} \sum_{j=1}^{4} \frac{C_{j} H_{j}}{D_{j}}
$$

where $H_{O S}$ is the height of a selected older sapling (in $\mathrm{cm}$ ), $C_{\mathrm{j}}$ is the percent surface covered by the competing saplings in quadrant $j, H_{j}$ is the mean height of the competing saplings in quadrant $j$ (in $\mathrm{cm}$ ), and $D_{j}$ is the mean distance between the competing saplings in quadrant $j$ and the selected older sapling (in $\mathrm{cm}$ ).

In the centre of each sample plot, hemispherical photographs were taken at $1.3 \mathrm{~m}$ and $3.5 \mathrm{~m}$ above the ground (upper limits for categories of younger and older saplings) to assess the light environment. The amount of natural regeneration quantified by sapling density was subsequently analysed in relation to the light conditions. Additionally, hemispherical photographs were made above the terminal shoots of all 260 selected older saplings. We used a Nikon CoolPix ${ }^{\circledast}$ P5000 10 MP camera (Nikon Inc., Tokyo, Japan) with an $8 \mathrm{~mm}$ fish-eye lens converter FC-E8 and a self-levelling mount (Regent Instruments Inc., Sainte-Foy, Quebec, (anada) installed on a telescopic tripod Manfrotto with a maximum height of $7.3 \mathrm{~m}$. Hemispherical photographs were taken from July-September 2013 under overcast skies or after sunset to avoid the influence of direct solar radiation. The acquired images were processed using the software WinSCANOPY 2006b (Regent Instruments Inc.) using an automatic pixel classification based on grey scale. The local light conditions were quantified by the ratio between the diffuse photosynthetic photon flux density under and over the canopy that resulted from the analysis of hemispherical photographs ("indirect site factor" in WinSCANOPY 2006b).

In addition, we also analysed the age structure and past growth of a sample of lower overstory stems $(\mathrm{DBH}=8-12 \mathrm{~cm})$. For 50 randomly selected trees (28 Norway spruces and 22 silver firs) with a DBH near the upper limit of the first diameter class (10-12 cm), we carried out a complete stem analysis. The trees were cut directly above the ground, their total height was recorded and $2 \mathrm{~cm}$-thick cross-sections were taken at $0.5 \mathrm{~m}$ intervals along the stem, with the first cross-section taken at the stem base of the felled tree. In the laboratory, the samples were prepared according to standard methodology (Cook \& Kairiukstis 1990) and scanned at 1200 dpi using an Epson Expression $10000 \mathrm{XL}^{\oplus}$ scanner. The digitized cross-sections were subsequently analysed using WinDENDRO 2009b software (Regent Instruments Inc.), and the number of rings was counted for each disc. Based on the method of Carmean (1972), we reconstructed the annual height growth of the analysed trees, which was subsequently used for the construction of the growth curves. The average annual height growth rate of the spruce and fir from the lower overstory was calculated according to the fitted species-specific age-height curves as the ratio of height and respective age.

\section{Statistical analyses}

All of the statistical analyses were performed using the software package $R$ ( $R$ Development Core Team 2018) and STATISTICA $^{\circledast}$ v.10.0 (StatSoft Inc. 2010). A finite mixture of two Weibull functions (sevenparameter form - Zhang et al. 2001) was fitted to the empirical diameter distributions of each measurement year and forest stand by the "mixdist" package of R software. The differences between the empirical diameter distributions and their equilibrium curves (Vencurik et al. 2016) were examined using a two-sample KolmogorovSmirnov test. For testing differences between the relative radiation in the $D 1 A$ and D2C, we used a t-test for independent samples. The relationships between diffuse light and sapling density were analysed using simple linear regression (Zar 1999).

Multiple linear regression was used to test the effect of multiple explanatory variables, including stand type, species, diffuse light and competition on the individual growth traits (y): tree height increment (both absolute and relative), apical dominance ratio and relative crown length. To quantify the competition status, two indices were tested: (i) the distance-dependent competition index I (complnd, eqn. 2); and (ii) the simple sum of the heights of the competing trees (sumHeight, eqn. 3). To quantify the effect of a variable within the levels of the other variables, we added linear interactions in the model. We developed the following model variants (eqn. 2, eqn. 3):

$$
\begin{aligned}
y_{i j} & =b_{0}+b_{1} \text { standType }_{i j}+b_{2} \text { species }_{i j} \\
& +b_{3} \text { compInd }_{i j}+b_{4} \text { difLight }_{i j} \\
& +b_{5} \text { compInd }_{i j} \text { difLight }_{i j}+\varepsilon \\
y_{i j} & =b_{0}+b_{1} \text { standType }_{i j}+b_{2} \text { species }_{i j} \\
& +b_{3} \text { sumHeight }_{i j}+b_{4} \text { difLight }_{i j} \\
& +b_{5} \text { sumHeight }_{i j} \text { difLight }_{i j}+\varepsilon
\end{aligned}
$$
2013 approached S-shaped curves (Fig. 1).

where $y$ is the growth trait of interest, $b_{0}-b_{5}$ are regression coefficients to be estithe basal area and volume.

The diameter distributions of the investigated stands in 1993 as well as those in

mated, the indices $i$ and $j$ denote the location in which a plot is placed and the observational plot itself, respectively, and $\varepsilon$ is the error term.

However, we found a significant correlation between complnd and diflight $\left(\mathrm{R}^{2}=\right.$ $0.17, p<0.05)$ as well as between sumHeight and difLight $\left(R^{2}=0.11, p<0.05\right)$. The variance inflation factor (calculated using the "vif" R function of the "car" package Fox \& Weisberg 2011) indicated that multicollinearity can strongly affect the estimation of the regression coefficients (VIF > 4 for both predictors). Therefore, with the aim of keeping all the predictor variables in the models, we first removed the relationship among these variables. The residuals from the relationship between diffuse light (predictor) and the competition index/sum of the heights (dependent variable) were then used in the model to represent the pure competition effect (the residuals replaced complnd and sumHeight in eqn. 2 and eqn. 3). We used "ggplot2" in R (Wickham 2016) to estimate the effects of the predictors with the respective $95 \%$ confidence intervals.

The age-height curves of the spruce and fir from the lower overstory were fitted using the Chapman-Richards function (eqn. 4):

$$
h=a\left(1-e^{-b t}\right)^{c}
$$

where $h$ is the tree height, $t$ is the age, and $a, b, c$ are coefficients to be estimated.

For the parameterization of the growth function we used the nonlinear method of least squares, and for the optimization, we used the derivate Rosenbrock and quasiNewton method in STATISTICA ${ }^{\circledast}$ v. 10.0.

\section{Results}

\section{Stand history and natural regeneration}

Between 1993 and 2013, the density of stems with a DBH $>8 \mathrm{~cm}$ decreased in both the studied stands, from $707 \mathrm{ha}^{-1}$ to $633 \mathrm{ha}^{-1}$ in the D1A and from $631 \mathrm{ha}^{-1}$ to $622 \mathrm{ha}^{-1}$ in the D2C (Tab. 1). At the same time, an increase in the basal area and growing stock was recorded. Regarding the tree species composition, we observed a substantial reduction in the spruce proportion, especially when considering the stem numbers (from $68 \%$ to $52 \%$ in the D1A and from $96 \%$ to $81 \%$ in the $\mathrm{D}_{2} \mathrm{C}$ ). The decrease in spruce was compensated by the increased proportion of other tree species, especially fir in the lower diameter classes (from $25 \%$ to $39 \%$ in the $\mathrm{D}_{1} \mathrm{~A}$ and from $3 \%$ to $17 \%$ in the $\mathrm{D}_{2} \mathrm{C}$ ). Although not of the same magnitude, similar The differences between the empirical and optimal (reverse J-shaped) distributions in both the measurement years and study sites remained significant $(p<0.05)$. During 
Tab. 1 - Basic stand characteristics (trees of DBH $>8 \mathrm{~cm}$ ) in investigated forests in 1993 and 2013. (*): European larch, Scots pine, rowan.

\begin{tabular}{|c|c|c|c|c|c|}
\hline \multirow{2}{*}{ Characteristics } & \multirow{2}{*}{ Species } & \multicolumn{2}{|c|}{ D1A } & \multicolumn{2}{|c|}{ D2C } \\
\hline & & 1993 & 2013 & 1993 & 2013 \\
\hline \multirow[t]{5}{*}{ Stem density } & Total $\left(\mathrm{N} h a^{-1}\right)$ & 707 & 633 & 631 & 622 \\
\hline & Spruce (\%) & 68 & 52 & 96 & 81 \\
\hline & Fir (\%) & 25 & 39 & 3 & 17 \\
\hline & Beech (\%) & 5 & 8 & 0 & 1 \\
\hline & Others* $(\%)$ & 2 & 1 & 1 & 1 \\
\hline \multirow[t]{5}{*}{ Basal area } & Total $\left(m^{2} h a^{-1}\right)$ & 45 & 47 & 33 & 39 \\
\hline & Spruce (\%) & 72 & 61 & 97 & 87 \\
\hline & Fir (\%) & 24 & 33 & 3 & 13 \\
\hline & Beech (\%) & 1 & 2 & 0 & 0 \\
\hline & Others* $(\%)$ & 3 & 4 & 0 & 0 \\
\hline \multirow[t]{5}{*}{ Growing stock } & Total $\left(m^{3} h a^{-1}\right)$ & 495 & 519 & 363 & 438 \\
\hline & Spruce (\%) & 71 & 62 & 97 & 87 \\
\hline & Fir (\%) & 26 & 33 & 3 & 13 \\
\hline & Beech (\%) & 1 & 1 & 0 & 0 \\
\hline & Others* $(\%)$ & 2 & 4 & 0 & 0 \\
\hline
\end{tabular}

the study period, we recorded moderately increased stem numbers in diameter classes $\geq 38 \mathrm{~cm}$ and underrepresented numbers of trees in the lower diameter classes.

The overall density of the regeneration (i.e., all the individuals, from seedlings to undergrowth, with a $\mathrm{DBH} \leq 8 \mathrm{~cm}$ ) in the studied stands was $21,461 \pm 2,380 \mathrm{ha}^{-1}$ in the D1A and 15,016 $\pm 2,697$ ha $^{-1}$ in the D2C. In the regeneration, four tree species were present: naturally regenerated spruce, fir, rowan as well as underplanted beech (Tab. 2 ). In both stands and in all but one regeneration category (younger saplings in the D2C), the proportion of fir was significantly higher than in the overstory. Regarding the regeneration categories, the share of spruce in the seedlings and younger sap- lings categories was higher than in the older saplings and undergrowth categories. An opposite trend of increasing proportion with regeneration age was observed for the fir, which showed higher proportions in the categories of older saplings and undergrowth. The most frequently damaged tree species in both the investigated stands was fir, with the damage concentrated above all to the categories of older saplings and undergrowth. However, the damage in any category of regeneration did not exceed $15 \%$. The dominant type of damage was caused by ungulates (browsing and bark stripping). The regeneration of spruce, beech and rowan was damaged only sporadically $(<1 \%)$.

The light microclimate in the sample plots did not differ significantly between the in vestigated sites $(t=0.581, p=0.568$ in height $1.3 \mathrm{~m}$ and $t=0.447, \mathrm{p}=0.660$ in height $3.5 \mathrm{~m}$ ). The median values of the relative diffuse light reached $13.2 \%$ (D1A) and $12.0 \%\left(D_{2} C\right)$ at $1.3 \mathrm{~m}$ height and $14.7 \%(\mathrm{D} 1 \mathrm{~A})$ and $13.0 \%\left(D_{2} C\right)$ at $3.5 \mathrm{~m}$ height. For Norway spruce, significant correlations between the relative diffuse light and sapling density were found in both categories (younger saplings: $R=0.47, p=0.008$; older saplings: $R=0.57, p=0.001$ ), but only in the D1A (Fig. S1 in Supplementary material). In silver fir, no significant relationship between relative light and the sapling density was revealed in any category or site.
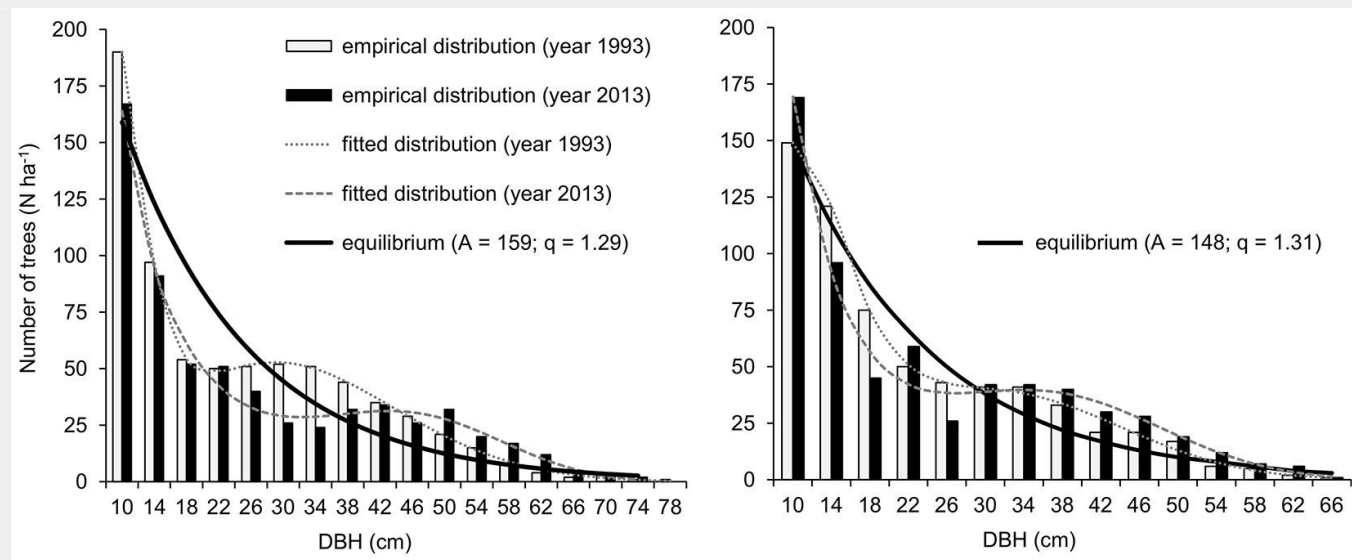

Fig. 1 - Equilibrium curves and diameter distributions recorded in the D1A (left) and the $D_{2} C$ (right).

Tab. 2 - Density and species composition of regeneration (mean \pm standard error) in investigated forests in 2013.

\begin{tabular}{|c|c|c|c|c|c|c|c|c|c|}
\hline \multirow{2}{*}{ Stand } & \multirow{2}{*}{ Species } & \multicolumn{2}{|c|}{ Seedlings } & \multicolumn{2}{|c|}{ Younger saplings } & \multicolumn{2}{|c|}{ Older saplings } & \multicolumn{2}{|c|}{ Undergrowth } \\
\hline & & $\mathrm{N} \mathrm{ha}^{-1}$ & $\%$ & $\mathrm{~N} \mathrm{ha}^{-1}$ & $\%$ & $\mathrm{~N} \mathrm{ha}^{-1}$ & $\%$ & $\mathrm{~N} \mathrm{ha}^{-1}$ & $\%$ \\
\hline \multirow[t]{5}{*}{ D1A } & Spruce & $6,338 \pm 1623$ & 51 & $2,723 \pm 844$ & 41 & $457 \pm 102$ & 25 & $138 \pm 29$ & 22 \\
\hline & Fir & $5,476 \pm 801$ & 44 & $3,246 \pm 387$ & 49 & $1,254 \pm 231$ & 69 & $451 \pm 82$ & 70 \\
\hline & Beech & - & - & $62 \pm 36$ & 1 & $112 \pm 29$ & 6 & $51 \pm 17$ & 8 \\
\hline & Rowan & $538 \pm 203$ & 5 & $615 \pm 126$ & 9 & - & - & - & - \\
\hline & Total & $12,352 \pm 1812$ & 100 & $6,646 \pm 943$ & 100 & $1,823 \pm 235$ & 100 & $640 \pm 79$ & 100 \\
\hline \multirow[t]{5}{*}{$\mathrm{D} 2 \mathrm{C}$} & Spruce & $4,000 \pm 965$ & 67 & $6,080 \pm 1655$ & 86 & $810 \pm 165$ & 53 & $250 \pm 47$ & 57 \\
\hline & Fir & $1,760 \pm 905$ & 29 & $700 \pm 139$ & 10 & $515 \pm 117$ & 34 & $174 \pm 43$ & 40 \\
\hline & Beech & - & - & $40 \pm 40$ & 1 & $195 \pm 103$ & 13 & $12 \pm 8$ & 3 \\
\hline & Rowan & $260 \pm 113$ & 4 & $220 \pm 93$ & 3 & - & - & - & - \\
\hline & Total & $6,020 \pm 1360$ & 100 & $7,040 \pm 1729$ & 100 & $1,520 \pm 205$ & 100 & $436 \pm 59$ & 100 \\
\hline
\end{tabular}




\section{Growth of older saplings}

The intensity of relative diffuse light measured above the terminal shoot of the analysed spruces and firs ranged from 7.2 to $26.7 \%$ in the studied stands. Under these light conditions, the values of the relative growth ratio varied between $0.3 \%$ and $10.7 \%$ for the spruce and between $0.2 \%$ and $13.2 \%$ for the fir (Tab. 3, Fig. S2 in Supplementary material).

The competition index (complnd) performed better than the sum of the heights of the competitors (sumHeight) regarding the explained variability in the growth traits (Tab. S1). Therefore, in the following analysis, we interpreted the results of the first variant (eqn. 2). The proportion of the variability explained by the predictors ranged from 36\% (apical dominance ratio) to $52 \%$ (height increment). The diffuse light and stand type variables most significantly affected the growth traits tested in the study ( $p<0.001-$ Fig. 2 ). However, diffuse light explained most of the variability in all the growth traits, ranging from $22 \%$ (apical dominance ratio) to $34 \%$ (height increment). The competition status showed a negative correlation, but only for the relative crown length (proportion of the variability explained was $7.4 \%, p<0.001$ ). The interaction between competition and diffuse light was only significant for the relative crown length and showed a positive effect of increased diffuse light at the same competition level $(2.3 \%$ of the total variability, $p<0.001)$. Except for the apical dominance ratio, we found that the tree species significantly contributed to the explanation of the total variability in the growth traits ( $5-8 \%$ of the total variability, $p$ $<0.001$ )

Age structure and height growth of the lower overstory trees

The age of the analysed spruce and fir trees (DBH 10-12 cm) varied between 40 and 99 years (median value 52 years) in the D1A and between 32 and 107 years (median value 47 years) in the $D_{2} C$. The majority of the trees $\left(83 \%\right.$ in the $\mathrm{D}_{1 \mathrm{~A}}$ and $88 \%$ in the $\mathrm{D} 2 \mathrm{C}$ ) reached the upper limit of the first diameter class (i.e., $12 \mathrm{~cm}$ ) at the age of 30-60 years (hereafter "normal-growing trees"). However, among the analysed samples, we found several trees that reached the given threshold at ages distinctively exceeding 60 years (hereafter "slow-growing trees" - Tab. 4, Fig. 3; Fig. S3 in Supplementary material). The slowgrowing trees were almost exclusively spruce individuals, and only one slowgrowing fir was found in the D1A. The average heights of the slow-growing trees reaching the upper limit of the first diameter class were $25-35 \%$ lower than those of the normal-growing trees.

For the calculation of the average annual height increment, we used the values of the fitted heights at the age of 60 years for both the normal- and slow-growing trees. The height growth rate of the normal-
Tab. 3 - Basic characteristics of older saplings (mean \pm standard error; the range is given in parentheses).

\begin{tabular}{lcccc}
\hline \multirow{2}{*}{ Parameter } & \multicolumn{2}{c}{ D1A } & \multicolumn{2}{c}{ D2C } \\
\cline { 2 - 5 } & Spruce & Fir & Spruce & Fir \\
\hline $\begin{array}{l}\text { Height } \\
(\mathrm{cm})\end{array}$ & $189 \pm 6$ & $210 \pm 6$ & $186 \pm 6$ & $206 \pm 6$ \\
\hline $\begin{array}{l}\text { Mean height increment } \\
(\mathrm{cm} \text { year }\end{array}$ & $(131-308)$ & $(130-324)$ & $(131-311)$ & $(130-310)$ \\
\hline $\begin{array}{l}\text { Relative growth ratio } \\
(\%)\end{array}$ & $8.9 \pm 0.7$ & $12.9 \pm 0.9$ & $5.7 \pm 0.5$ & $8.6 \pm 0.6$ \\
\hline Apical dominance ratio & $(0.7-30.0)$ & $(1.0-30.5)$ & $(0.8-16.5)$ & $(0.5-21.2)$ \\
& $4.6 \pm 0.4$ & $6.1 \pm 0.4$ & $3.1 \pm 0.3$ & $3.8 \pm 0.3$ \\
\hline $\begin{array}{l}\text { Relative crown length } \\
(\%)\end{array}$ & $(0.3-10.7)$ & $(0.8-13.2)$ & $(0.5-10.3)$ & $(0.2-10.6)$ \\
\hline Competition index & $0.9 \pm 0.1$ & $0.9 \pm 0.1$ & $0.7 \pm 0.1$ & $0.7 \pm 0.1$ \\
& $(0.1-1.8)$ & $(0.3-1.6)$ & $(0.3-1.5)$ & $(0.1-1.6)$ \\
\hline & $68.7 \pm 1.5$ & $74.5 \pm 1.8$ & $58.6 \pm 2.5$ & $70.7 \pm 1.8$ \\
\hline & $(27.3-90.1)$ & $(20.7-95.2)$ & $(17.2-88.2)$ & $(40.1-93.3)$ \\
\hline
\end{tabular}

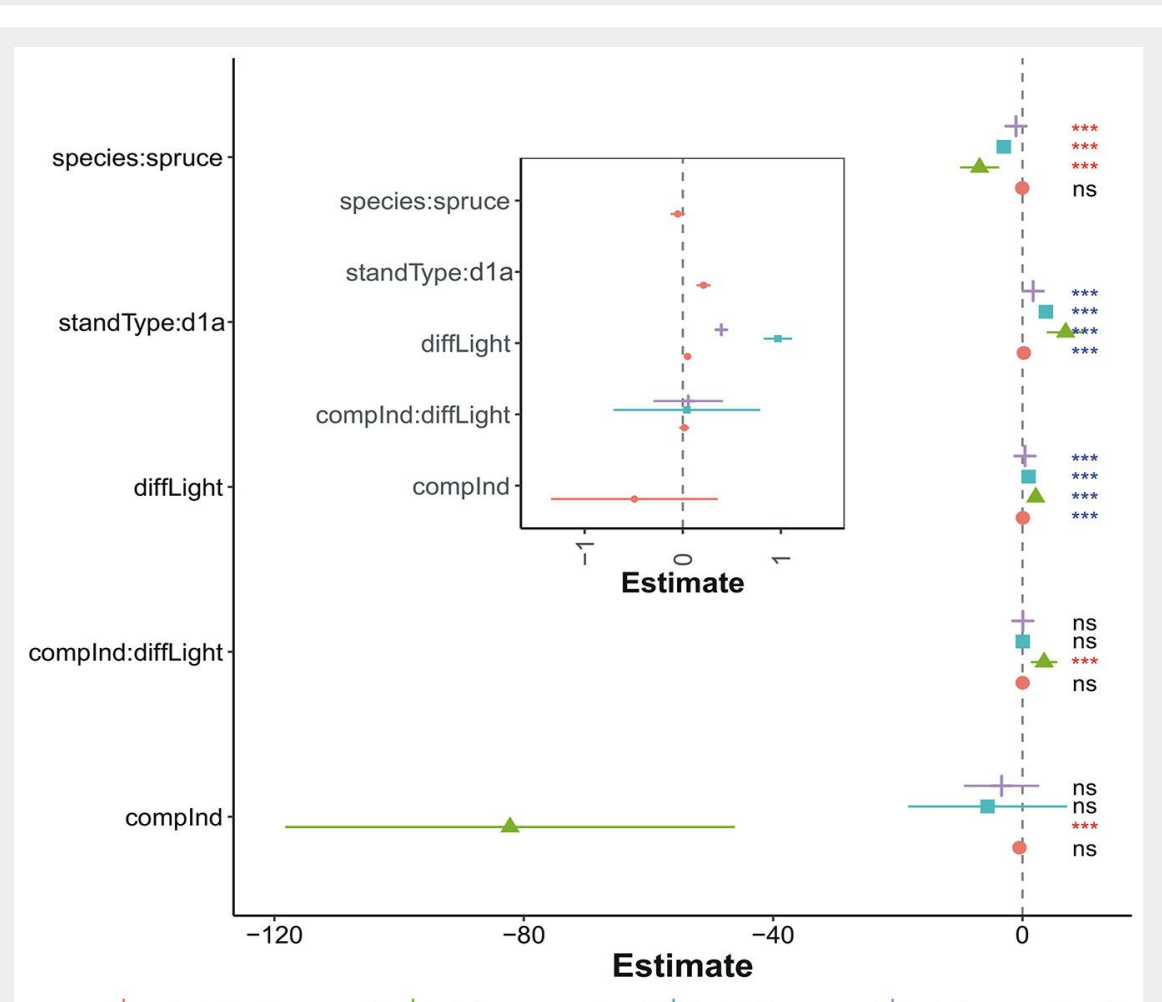

$\phi$ apical dominance ratio $\uparrow$ relative crown length ${ }^{\dagger}$ height increment + relative growth ratio

Fig. 2 - Estimation of coefficients of the multiple linear regression model (fitted by eqn. 2). The coefficients express the effects of predictors on the individual growth traits (height increment, relative growth ratio, apical dominance ratio and relative crown length). The inner graph zooms in the predictors that have the coefficients values close to zero. The whiskers denote $95 \%$ confidence intervals. (standType): stand type; (diffLight): diffuse light; (complnd): competition index; $\left({ }^{*}\right): p<0.05 ;\left({ }^{* *}\right): p<$ $0.01 ;(* * *): p<0.001 ;(n s):$ not significant.

Tab. 4 - Parameters of age-height curves fitted with the Chapman-Richards function.

\begin{tabular}{llrcccc}
\hline Density & Species & No & $\boldsymbol{a}$ & $\boldsymbol{b}$ & $\boldsymbol{c}$ & $\mathbf{R}$ \\
\hline D1A & Normal-growing spruce & 9 & 13.329 & -0.070 & 5.555 & 0.954 \\
\cline { 2 - 7 } & Slow-growing spruce & 3 & 11.563 & -0.032 & 4.928 & 0.955 \\
\cline { 2 - 7 } & Normal-growing fir & 11 & 14.354 & -0.045 & 3.477 & 0.969 \\
\cline { 2 - 7 } D2C & Slow-growing fir & 1 & 127.990 & -0.001 & 1.078 & 0.992 \\
& Normal-growing spruce & 13 & 12.272 & -0.059 & 3.636 & 0.906 \\
& Slow-growing spruce & 3 & 19.223 & -0.011 & 2.169 & 0.862 \\
& Normal-growing fir & 10 & 19.763 & -0.040 & 3.717 & 0.942 \\
\hline
\end{tabular}



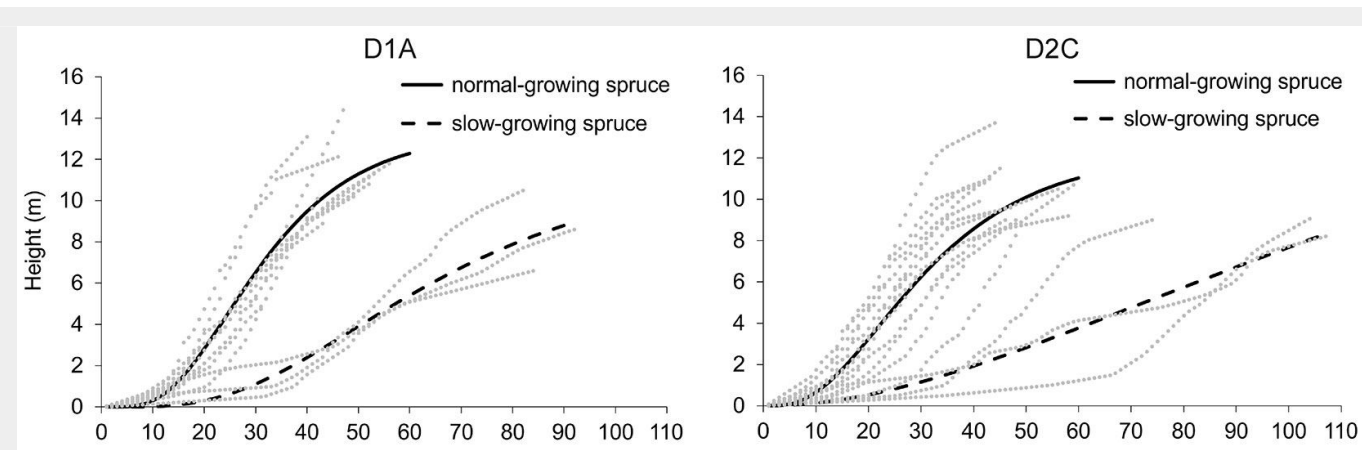

Fig. 3 - Growth curves of individual lower overstory trees (DBH 10-12 cm) with fitted species-specific ageheight curves
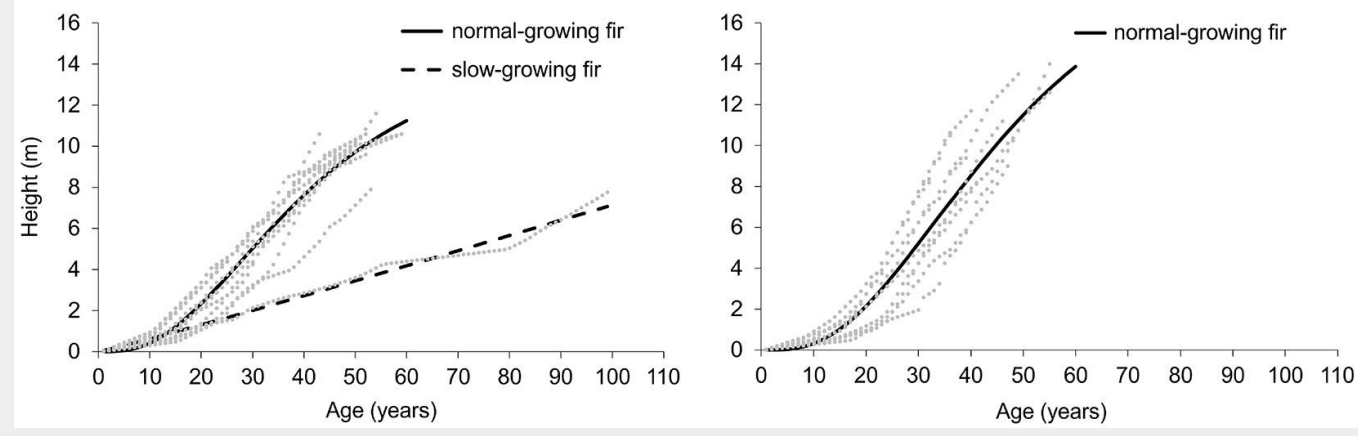

growing trees reached $18.4 \mathrm{~cm}$ in the $\mathrm{D}_{2} \mathrm{C}$ and $20.5 \mathrm{~cm}$ in the D1A per year for the spruce and 18.7 to $23.1 \mathrm{~cm}$ per year for the fir. Regarding the slow-growing trees, the rates were considerably lower, with a range of $6.3-9.0 \mathrm{~cm}$ per year.

\section{Discussion}

Stand structure, natural regeneration and effect of light on sapling density

The results of this study indicate that the investigated stands still show certain deviations from the optimal diameter distributions and tree species composition (e.g., overrepresented spruce, absence of natural regeneration of beech, etc.). Low intensity of silvicultural interventions in the last two decades resulted in an increase in stem density and volume in the upper diameter classes and a decrease in the lower diameter classes of the stands (Tab. 1, Fig. 1). The progress of the ongoing conversion process was slowed, and therefore, the achievement of the optimal selection structure was delayed as well. In both of the studied stands, the share of the trees with a DBH $>36 \mathrm{~cm}$ in the growing stock $(80 \%$ in the $D_{1} A$ and $67 \%$ in the $D_{2} C$ ) was considerably higher compared with the theoretical structure (61\% and $54 \%$ ). As a consequence, the current growing stock significantly exceeds the optimal levels $\left(410 \mathrm{~m}^{3} \mathrm{ha}^{-1}\right.$ for the $D_{1} A$ and $320 \mathrm{~m}^{3}$ ha $^{-1}$ for the $\mathrm{D}_{2} \mathrm{C}$ ), by $26 \%$ (D1A) or $37 \%$ (D2C). Nevertheless, due to underrepresented numbers of trees in the lower diameter classes, the amount of transmitted solar radiation (median values $13.2 \%$ in the $\mathrm{D}_{1} \mathrm{~A}$ and $12 \%$ in the $\mathrm{D}_{2} \mathrm{C}$ ) was higher in comparison with similar studies performed in spruce-fir (beech) selection forests with diffuse light levels between 3.9 and $6.4 \%$ (Boncina et al. 2002, Diaci \& Firm 2011). This structure allowed the ad- vanced natural regeneration (i.e., older saplings and undergrowth) to survive in large numbers, which exceeds the threshold value of $600 \mathrm{ha}^{-1}$ reported by Duc (1991), the value necessary for the maintenance of selection structure in spruce-fir forests. Regarding the future development of the two analysed conversion stands, the regular application of silvicultural interventions that gradually reduces the density of large-diameter stems can increase the transition rate between the lower and upper overstory and significantly improve the differentiation of stand structure (Schütz 2001b, Cameron \& Hands 2010).

In the investigated stands, we observed a progressive change in the representation of the main tree species, spruce and fir. During the previous two decades, a visible increase in the fir proportion at the expense of spruce was observed in the parent stand, especially in the lower overstory. Moreover, fir became established also in the understory (Tab. 1, Tab. 2). The main reason for the increasing proportion of fir was probably the low intensity of diffuse light in the stand. Shaded conditions do not allow spruce to realize its high growth potential, and under such conditions, fir is a stronger competitor (Grassi \& Bagnaresi 2001, Stancioiu \& O'Hara 2006, Danescu et al. 2018). Another important factor to be considered is the impact of ungulates, as the overbrowsing of regeneration was identified by several studies (Klopcic et al. 2010, Diaci et al. 2011) as one of the main reasons for fir decline in Europe. In the stands surveyed in our study, the low density of ungulates (personal observation), causing only insignificant damage to fir regeneration, was very likely another reason for the current successful development of fir regeneration.

The natural regeneration of fir prefers mostly microsites under stand canopies or at the edges of canopy gaps (Grassi et al. 2004, Diaci et al. 2005, Paluch 2005). Here, fir survival is limited by light, with the minimal required values from $2 \%$ for seedlings to $10 \%$ for 5 - to 15 -year-old saplings (Givnish 1988, Jaworski 1995). The lower ability of fir saplings to utilize high-light conditions compared to spruce was confirmed also by Grassi \& Bagnaresi (2001). The results of our study, similar to those of Cescatti (1996), indicate that the density of fir saplings was not significantly affected by sunlight. The same situation was observed for spruce in the $D_{2} C$, while the only positive correlation between diffuse light and regeneration density was confirmed for spruce in the D1A (Fig. S1 in Supplementary material). We assume that in the $\mathrm{D}_{2} \mathrm{C}$, the influence of diffuse light was confounded by less favourable soil conditions (Vencurik et al. 2016) that can play a decisive role in the regeneration processes of spruce as well as fir (Diaci et al. 2005, Paluch 2005). Another major factor could be the competition of ground vegetation (Filipiak et al. 2005, Szymura et al. 2007), represented by large patches of Vaccinium myrtillus in the D2C (Vencurik et al. 2016). However, the dynamics of regeneration processes can be affected also by other factors, such as seed dispersal (Szymura et al. 2007), micro-relief (Diaci et al. 2005), seedbed characteristics (Simard et al. 1998) or the tree species composition of the canopy layer (Paluch 2005, Cavlović et al. 2006).

\section{Impact of site conditions and neigh- bourhood characteristics on saplings' growth}

Recently, the analysis of the height growth of spruce and fir natural regeneration in uneven-aged, mixed forests was the object of several studies (Szymura 2005, 
Stancioiu \& O'Hara 2006, Diaci \& Firm 2011). A direct comparison of the results was nevertheless problematic because there were considerable differences in the height range of the surveyed samples. In general, the relative height increments reported for the natural regeneration of spruce and fir in the mentioned studies varied between $5 \%$ and $11 \%$. In our study, comparable results were observed for the older saplings in the D1A; however, in the less favourable site conditions of the $D_{2} C$, the relative height increment along the examined light gradient was distinctively lower (Tab. 3). Similar to our results (Fig. 2), the positive impact of diffuse light on the height growth of spruce as well as fir with heights $<2.2 \mathrm{~m}$ was confirmed also by the studies of Filipiak et al. (2005) and Grassi \& Giannini (2005). On the contrary, in the study of Diaci \& Firm (2011) no correlation between height increment and diffuse light was revealed for spruce and fir seedlings. The authors observed a significant relationship only in the sapling category (height 20-130 cm), with significantly larger height increments of fir. Under average diffuse light levels of $6-8 \%$, the annual height increment of fir exceeded that of spruce by approximately $1 \mathrm{~cm}$, corresponding to the results of our study (Fig. 2 and Fig. S2 in Supplementary material). Similar results were confirmed by Stancioiu \& O'Hara (2006) from mixed mountain forests in Romania. In low-light environments (relative irradiance $<35 \%$ ), the height increments of the fir and beech saplings reached significantly higher values than those of spruce. In contrast, in intermediate light conditions (relative irradiance 35$70 \%$ ), the authors registered comparable height growth of all the tree species and in open conditions (relative irradiance $>70 \%$ ), even the tendency of spruce to outgrow beech and fir.

The ability of saplings to effectively use solar radiation is crucially affected by the morphologies of their assimilatory apparatuses (Oliver \& Larson 1996). Therefore, the apical dominance ratio and the relative crown length of conifer saplings could be regarded as simple indicators of light conditions (Parent \& Messier 1995, Robakowski et al. 2004, Szymura 2005), especially for spruce, as was documented by our results (Fig. S2). In general, the lower the apical dominance ratio, the more seedling growth is affected by light deficiency (Grassi \& Giannini 2005). In our study, the threshold value of 1 was reached at relative radiation levels of $18 \%$ (fir) and 19\% (spruce) in the D1A; however, in the $\mathrm{D}_{2} \mathrm{C}$, the threshold value was reached only after the relative light exceeded 22\% (fir) and $26 \%$ (spruce - Fig. S2 in Supplementary material). This indicates that the more severe a site is, the higher are the saplings' demands for light. For silviculture in sites with less favourable growth conditions, it is therefore recommended to adequately reduce the period of shading (Burschel \&
Huss 1997). Under such conditions, in the stands undergoing conversion, it is useful to reduce the canopy density more strongly and keep the growing stock at a lower level. Nevertheless, a too strong intervention can result in the establishment of spatially continuous, even-aged natural regeneration that, regarding stand differentiation, should be avoided (Schütz 2001b, Saniga \& Vencurik 2007). As registered in our study, the spruce and fir reacted to changes in the light microclimate, showing differences in height growth and relative crown length. The observed differences between these two species in height growth can most likely be attributed to the physiological characteristics of the needles, with better adaptation of fir to low light environments. The differences could also be attributed to the better ability of fir saplings to adjust their crowns to changing light conditions (Grassi \& Bagnaresi 2001, Robakowski et al. 2004).

Along the examined light gradient (relative radiation $7-27 \%$ ), we observed a negative influence of local sapling density (competition index) only on the relative crown length of the older saplings of spruce and fir (Fig. 2). In contrast, no significant relationship was confirmed between local sapling density and height growth or the apical dominance ratio. Several studies (Klinka et al. 1992, Grassi \& Giannini 2005) have suggested that in shaded conditions, light has by far the highest influence on tree growth, and light usually overlay the impact of the other factors including local sapling density. Intraspecific competition was confirmed to affect the height increment only in non-limiting light conditions (Parent \& Messier 1995, Duchesneau et al. 2001). We therefore assume, that lower values of diffuse light registered in the conversion stands in our study were the main reason why the local sapling density did not play any important role in the height growth of older saplings. Nevertheless, the generalization of these results is limited by the fact that we analysed only the height growth of the highest saplings in the clusters.

\section{Long-term growth dynamics of the lower overstory trees}

Continuous ingrowth of natural regeneration into the smallest diameter classes is the basic feature of a system's self-regulation that, in conversion stands, begins to function only after a relatively long time period. Based on the analysis of 100 years of conversion from regular afforestation to currently differentiated, spruce-dominated forest stands in Swiss Jura, Schütz (2001a) concluded that the formation of irregular vertical structures requires at least 60-70 years. This estimation more or less corresponds with the findings from our stands, where the majority of the young spruces and firs ("normal-growing trees") reached the upper limit of the first diameter class at approximately 50 years, with an average height growth rate of $18-23 \mathrm{~cm}$ per year (Fig. 3 and Fig. $\mathrm{S}_{3}$ in Supplementary material). Despite the different site conditions, the lower growing stock and thus the more favourable light microclimate for the growth of the regeneration and lower overstory in the $D_{2} C$ resulted in the similar ages of the normal-growing trees, reaching the DBH threshold in both the investigated stands. In particular, the light-activated trees that are continuously growing up to the higher stand layers are critical for the maintenance of the equilibrium state of a selection forest (Schütz 2001a, Sterba \& Zingg 2001). In addition to the trees of average growth, in the studied stands were rarely present also slow-growing spruce and fir trees with average height increment less than $10 \mathrm{~cm}$ (mainly in the parts with complicated access and therefore a lower cutting intensity). Such trees can survive under the stand canopy for a very long period (in special cases more than 200 years) and form the potential reserve for the transitions into higher tree layers. After the release, they are able to reach dimensions comparable to the normal-growing trees regardless of their age (Lin et al. 2012).

Considering the decreasing height increment rate during the previous 20 years (Fig. 3), we assume that a more regular application of silvicultural interventions in both of the investigated stands during this period, especially a more substantial reduction in large overstory stems, would considerably promote the growth of fir and especially spruce regeneration and ingrowth to the overstory. As confirmed by several studies (Saniga \& Vencurik 2007, Cavlović et al. 2006, Cameron \& Hands 2010), stand structures with excessive growing stock negatively affect the density of natural regeneration, the transition of saplings into the lower overstory and the further transition into the higher stand layers. If the stand density exceeds a certain threshold, regeneration is no longer able to provide enough saplings for continuous height transitions, and the selection structure will be progressively lost (Schütz 2006). Moreover, low light levels can also influence the tree species composition of the understory, as this represents a competitive disadvantage for spruce against fir (Danescu et al. 2018). In conversion stands, where forest managers usually have to address this kind of problem, the recommended solution could be the regular application of classical differentiation thinning (sensu Schütz 2001b) focused on the refinement of the structure and improvements towards the equilibrium state of a selection forest.

\section{Conclusions}

Our results showed that the formation of lower overstory in stands undergoing the conversion to single-tree selection requires a time period of about 50 years. In these conditions, height growth of fir and spruce natural regeneration was significantly influ- 
enced by the intensity of diffuse radiation, but not the local sapling density. Natural regeneration of fir showed better dynamics of height growth than spruce. Considering the current negative impacts of climate change, especially on spruce, lower growing stocks in the stands could provide more suitable conditions for spruce regeneration and therefore contribute to its maintenance in spruce-fir mixtures. Results on conversion of monospecific forest stands to mixed diverse forest structures are an important step toward an understanding and cultivating stable forest ecosystems resilient to disturbances.

\section{Authors' contributions statement}

The study was conducted with contributions from all authors. JV, MS and SK designed and planned the study. JV, DS, JP and ZP conducted the field measurements and laboratory work. MB and JV performed the statistical analyses. JV, SK and PJ analyzed and interpreted data. JV prepared the draft of the manuscript.

\section{Acknowledgements}

This research was funded by the Ministry of Education, Science, Research and Sports of the Slovak Republic - Scientific Grant Agency (VEGA), projects VEGA 1/0492/17 and VEGA 1/0021/18.

\section{Conflict of interest}

The authors declare that they have no conflict of interest.

\section{References}

Augusto L, Ranger J, Binkley D, Rothe A (2002). Impact of several common tree species of European temperate forests on soil fertility. Annals of Forest Science 59: 233-253. - doi: 10.1051/ forest:2002020

Boden S, Kahle HP, Wilpert K, Spiecker H (2014). Resilience of Norway spruce (Picea abies (L.) Karst) growth to changing climatic conditions in Southwest Germany. Forest Ecology and Management 315: 12-21. - doi: 10.1016/j.foreco.20 13.12.015

Boncina A, Diaci J, Cencic L (2002). Comparison of the two main types of selection forests in Slovenia: distribution, site conditions, stand structure, regeneration and management. Forestry 75: 365-373. - doi: 10.1093/forestry/75.4.3 65

Bošela M, Sedmák R, Sedmáková D, Marušák R, Kulla L (2014). Temporal shifts of climategrowth relationships of Norway spruce as an indicator of health decline in the Beskids, Slovakia. Forest Ecology and Management 325: 108-117. - doi: 10.1016/j.foreco.2014.03.055

Brang P, Spathelf P, Larsen JB, Bauhus J, BonČina A, Chauvin C, Drössler L, Güemes CG, Heiri C, Kerr G, Lexer MJ, Mason B, Mohren F, Mühlethaler U, Nocentini S, Svoboda M (2014). Suitability of close-to-nature silviculture for adapting temperate European forests to climate change. Forestry 87: 492-503. - doi: 10.1093/for estry/cpuo18

Burschel P, Huss J (1997). Grundriß des Waldbaus [Silviculture]. Parey Buchverlag, Berlin,
Germany, pp. 487. [in German]

Cameron AD, Hands MOR (2010). Developing a sustainable irregular structure: an evaluation of three inventories at 6-year intervals in an irregular mixed-species stand in Scotland. Forestry 83: 469-475. - doi: 10.1093/forestry/cpq029 Carmean WH (1972). Site index curves for upland oaks in the Central States. Forest Science 18: 102-120. - doi: 10.1093/forestscience/18.2.109

Cavlović J, Bozić M, Boncina A (2006). Stand structure of an uneven-aged fir-beech forest with an irregular diameter structure: modeling the development of the Belevine forest, Croatia. European Journal of Forest Research 125: 325-333. - doi: 10.1007/s10342-006-0120-z

Cescatti A (1996). Selective cutting radiative regime and natural regeneration in a mixed coniferous forest. In: "Modelling Regeneration Success and Early Growth of Forest Stands" (Skovsgaard JP, Johannsen P eds). Danish Forest and Landscape Research Institute, Horsholm, Denmark, pp. 474-483.

Cook ER, Kairiukstis LA (1990). Methods of dendrochronology: applications in the environmental sciences. Kluwer Academic Publishers, Dordrecht, Netherlands, pp. 394.

Danescu A, Kohnle U, Bauhus J, Weiskittel A, Albrecht AT (2018). Long-term development of natural regeneration in irregular, mixed stands of silver fir and Norway spruce. Forest Ecology and Management 430: 105-116. - doi: 10.1016/j. foreco.2018.07.055

Dengler A (1980). Waldbau [Silviculture]. Verlag Paul Parey, Hamburg, Berlin, Germany, pp. 350. [in German]

Diaci J, Pisek R, Boncina A (2005). Regeneration in experimental gaps of subalpine Picea abies forest in the Slovenian Alps. European Journal of Forest Research 124: 29-36. - doi: 10.1007/s10 342-005-0057-7

Diaci J, Firm D (2011). Long-term dynamics of a mixed conifer stand in Slovenia managed with a farmer selection system. Forest Ecology and Management 262: 931-939. - doi: 10.1016/j.for eco.2011.05.024

Diaci J, Rozenbergar D, Anic I, Mikac S, Saniga M, Kucbel S, Visnjic C, Ballian D (2011). Structural dynamics and synchronous silver fir decline in mixed old-growth mountain forests in Eastern and Southeastern Europe. Forestry 84: 479-491. doi: 10.1093/forestry/cpro3o

Duc P (1991). Investigations on recruitment dynamics in Emmental selection forest plots. Schweizerische Zeitschrift für Forstwesen 142: 299-319. [in German]

Duchesneau R, Lesage I, Messier C, Morin H (2001). Effects of light and intraspecific competition on growth and crown morphology of two size classes of understory balsam fir saplings. Forest Ecology and Management 140: 215-225. doi: 10.1016/S0378-1127(00)00281-4

Dvorak L, Bachmann P, Mandallaz D (2001). Sturmschäden in ungleichförmigen Beständen [Storm damage in irregular stands]. Schweizerische Zeitschrift für Forstwesen 152: 445-452. [in German] - doi: 10.3188/szf.2001.0445

Filipiak M, Iszkulo G, Korybo J (2005). Relation between photosynthetic photon flux density (PPFD) and growth of silver fir (Abies alba Mill.) seedlings in a forest stand dominated by spruce [Picea abies (L.) Karst.] in the Sudety
Mts (SW Poland). Polish Journal of Ecology 53: 177-184. [online] URL: http://www.researchga te.net/publication/286884540

Fox J, Weisberg S (2011). An R companion to applied regresion ( $2^{\text {nd }}$ edn). Sage, Thousand Oaks, CA, USA, pp. 608. [online] URL: http://us.sage pub.com/en-us/nam/an-r-companion-to-applied -regression/book246125

Gamborg C, Larsen JB (2003). "Back to nature” a sustainable future for forestry? Forest Ecology and Management 179: 559-571. - doi: 10.101 6/S0378-1127(02)00553-4

Givnish TJ (1988). Adaptation to sun and shade: a whole-plant perspective. Australian Journal of Plant Physiology 15: 63-92. - doi: 10.1071/PP9 880063

Grassi G, Bagnaresi U (2001). Foliar morphological and physiological plasticity in Picea abies and Abies alba saplings along a natural light gradient. Tree Physiology 21: 959-967. - doi: 10.1093/treephys/21.12-13.959

Grassi G, Minotta G, Tonon G, Bagnaresi U (2004). Dynamics of Norway spruce and silver fir natural regeneration in a mixed stand under uneven-aged management. Canadian Journal of Forest Research 34: 141-149. - doi: 10.1139/ x03-197

Grassi G, Giannini R (2005). Influence of light and competition on crown and shoot morphological parameters of Norway spruce and silver fir saplings. Annals of Forest Science 62: 269-274. doi: 10.1051/forest:2005019

Heuze P, Schnitzler A, Klein F (2005). Is browsing the major factor of silver fir decline in the Vosges Mountains of France? Forest Ecology and Management 430: 219-228. - doi: 10.1016/j.for eco.2005.06.003

Jaworski A (1995). Silvicultural characteristic of forest trees. Gutenberg, Kraków, Poland, pp. 237. [in Polish]

Klinka K, Wang Q, Kayahara GJ, Carter RE, Blackwell BA (1992). Light-growth response relationships in Pacific silver fir (Abies amabilis) and subalpine fir (Abies lasiocarpa). Canadian Journal of Forest Research 70: 1919-1930. - doi: 10.11 39/b92-239

Klopcic M, Jerina K, Boncina A (2010). Long-term changes of structure and tree species composition in Dinaric uneven-aged forests: are red deer an important factor? European Journal of Forest Research 129: 277-288. - doi: 10.1007/s10 342-009-0325-z

Lin CJ, Laiho O, Lähde E (2012). Norway spruce (Picea abies L.) regeneration and growth of understory trees under single-tree selection silviculture in Finland. European Journal of Forest Research 131: 683-691. - doi: 10.1007/s10342-0110541-1

Mezei P, Grodzki W, Blaenec M, Jakuš R (2014). Factors influencing the wind-bark beetles' disturbance system in the course of an Ips typographus outbreak in the Tatra Mountains. Forest Ecology and Management 312: 67-77. doi: 10.1016/j.foreco.2013.10.020

Oliver CD, Larson BC (1996). Forest stand dynamics. John Wiley, New York, USA, pp. 520. Paluch J (2005). Spatial distribution of regeneration in West-Carpathian uneven-aged silver fir forests. European Journal of Forest Research 124: 47-54. - doi: 10.1007/s10342-005-0054-x Parent S, Messier C (1995). Effets d'un gradient 
de lumière sur la croissance en hauteur et la morphologie de la cime du sapin baumier régénéré naturellement [Effects of a light gradient on height growth and the morphology of the crown of naturally regenerated balsam fir]. Canadian Journal of Forest Research 25: 878885. [in French] - doi: 10.1139/x95-096

Pawlowski B, Sokolowski M, Wallisch K (1928). Die Pflanzenassoziationen des Tatra-Gebirges. Teil 7. Die Pflanzenassoziationen und die Flora des Morskie Oko-Tales [Plant associations of the Tatra Mountains. Part 7. Plant associations and flora of the Morskie Oko Valley]. Extrait de Bullettin de l'Academie Polonaise des Sciences et des Lettres 2: 205-272. [in German]

Prpić B, Seletković Z (2001). Ecological constitution of the silver fir. In: "Silver Fir in Croatia" (Matić S, Vukelić J, Prpić B, Vidaković M, Klepac $D$, Glavaš $M$, Ljuljka $B$, Figurić $M$, Jakovac $H$ eds). Tiskara Meić, Zagreb, Croatia, pp. 269276.

R Development Core Team (2018). R: a language and environment for statistical computing. $\mathrm{R}$ Foundation for Statistical Computing, Vienna, Austria. [online] URL: http://www.R-project.org Robakowski P, Wyka T, Samardakiewicz S, Kierzkowski D (2004). Growth, photosynthesis, and needle structure of silver fir (Abies alba Mill.) seedlings under different canopies. Forest Ecology and Management 201: 211-227. - doi: 10.101 6/j.foreco.2004.06.029

Saniga M, Vencurik J (2007). Dynamics of structure and regeneration processes of the forests in various phases of the conversion to a selection forest in forest management unit Korytnica. Vydavatelstvo Technickej univerzity, Zvolen, Slovakia, pp. 82. [in Slovak]

Schütz JP (2001a). Opportunities and strategies of transforming regular forests to irregular forests. Forest Ecology and Management 151: 87-94. - doi: 10.1016/S0378-1127(00)00699-X Schütz JP (2001b). Der Plenterwald und weitere Formen strukturierter und gemischter Wälder [Selection forest and other forms of structured and mixed forests]. Parey Buchverlag, Berlin, Germany, pp. 220. [in German]

Schütz JP (2006). Modelling the demographic sustainability of pure beech plenter forests in Eastern Germany. Annals of Forest Science 63: 93-100. - doi: 10.1051/forest:2005101

Schütz JP, Götz M, Schmid W, Mandallaz D (2006). Vulnerability of spruce (Picea abies) and beech (Fagus sylvatica) forest stands to storms and consequences for silviculture. European Journal of Forest Research 125: 291-302. - doi: 10.1007/s10342-006-0111-0

Seidl R, Thom D, Kautz M, Martin-Benito D, Peltoniemi M, Vacchiano G, Wild J, Ascoli D, Petr M, Honkaniemi J, Lexer MJ, Trotsiuk V, Mairota P, Svoboda M, Fabrika M, Nagel TA, Reyer CPO (2017). Forest disturbances under climate change. Nature Climate Change 7: 395-402. doi: $10.1038 /$ nclimate3303

Simard MJ, Bergeron Y, Sirois L (1998). Conifer seedling recruitment in a southwestern Canadian boreal forests: the importance of substrate. Journal of Vegetation Science 9: 575582. - doi: $10.2307 / 3237273$

Stancioiu PT, O'Hara KL (2006). Regeneration growth in different light environments of mixed species, multiaged, mountainous forests of Romania. European Journal of Forest Research 125: 151-162. - doi: 10.1007/s10342-0050069-3

StatSoft Inc. (2010). Electronic statistics textbook. Tulsa, OK, USA. [online] URL: http:// www.statsoft.com/textbook

Sterba H, Zingg A (2001). Target diameter harvesting - a strategy to convert even-aged forests. Forest Ecology and Management 151: 95-105. - doi: 10.1016/S0378-1127(00)00700-3

Szymura TH (2005). Silver fir saplings bank in seminatural stand: individuals architecture and vitality. Forest Ecology and Management 212: 101-108. - doi: 10.1016/j.foreco.2005.03.003

Szymura TH, Dunajski A, Aman I, Makowski M, Szymura M (2007). The spatial pattern and microsites requirements of Abies alba natural regeneration in the Karkonosze Mountains. Dendrobiology 58: 51-57. [online] URL: http://yadda. icm.edu.pl/yadda/element/bwmeta1.element.a gro-article-7069a620-ecfo-4122-967c-a4bdd1e3 o22d

Van Der Maaten-Theunissen M, Kahle HP, Van Der Maaten E (2013). Drought sensitivity of Norway spruce is higher than that of silver fir along an altitudinal gradient in southwestern Germany. Annals of Forest Science 70: 185-193. doi: 10.1007/s13595-012-0241-0

Vencurik J, Kucbel S, Saniga M, Jaloviar P (2016). Structure and height growth of natural regeneration in selection forests with different Norway spruce proportion in Slovakia. Technical university, Zvolen, Slovakia, pp. 64. [in Slovak] Vitali V, Büntgen U, Bauhus J (2018). Seasonality matters - The effects of past and projected sea- sonal climate change on the growth of native and exotic conifer species in Central Europe. Dendrochronologia 48: 1-9. - doi: 10.1016/j.den dro.2018.01.001

Von Lüpke B, Ammer C, Bruciamacchie M, Brunner A, Ceitel J, Collet C, Deuleuze C, Placido JD, Huss J, Jankovič J, Kantor P, Larsen JB, Lexer M, Löf M, Longauer R, Madsen P, Modrzynski J, Mosandl R, Pampe A, Pommering A, Tesar V, Thompson R, Zientarski J (2004). Silvicultural strategies for conversion. In: "Norway spruce conversion: options and consequences" (Spiecker H, Hansen J, Klimo E, Skovsgaard JP, Sterba $H$, von Teuffel $K$ eds). Brill, Leiden, Netherlands, pp. 121-164.

Wickham H (2016). ggplot2: Elegant graphics for data analysis. Springer Verlag, New York, USA, pp. 276. [online] URL: http://books.google. com/books?id=XgFkDAAAQBAJ

Zar JH (1999). Biostatistical analysis. Prentice Hall, New Jersey, USA, pp. 663.

Zhang L, Gove JH, Liu C, Leak WB (2001). A finite mixture of two Weibull distributions for modeling the diameter distributions of rotated-sigmoid, uneven-aged stands. Canadian Journal of Forest Research 31 (9): 1654-1659. - doi: 10.1139/ x01-086

\section{Supplementary Material}

Fig. S1 - Relationships between diffuse light and number of younger or older saplings of Norway spruce in D1A.

Fig. S2 - Mean height increment, relative growth ratio, apical dominance ratio and relative crown length of Norway spruce and silver fir as a function of diffuse light in the $D_{1} A$ and the $D_{2} C$.

Fig. S3 - Age analysis of the lower overstory trees in the $D_{1} A$ and the $D_{2} C$.

Tab. S1 - Goodness-of-fit (adjusted $\mathrm{R}^{2}$ ) of the two variants of multiple linear regression, where the first variant (eqn. 2) includes competition index (complnd) and the second (eqn. 3) replace the complnd by the sum of competitors heights (sumHeight).

Link:Vencurik_3183@supploo1.pdf 